\title{
Deradicalization in Central Java during the Covid-19 Pandemic
}

\author{
Amin Farih $^{1}$, Endang Supriadi ${ }^{2}$, Ririh Megah Safitri ${ }^{3}$, Muhammad Nuqlir Bariklana ${ }^{4}$, Nafisah $^{5}$ \\ \{amin.farih@walisongo.ac.id ${ }^{1}$, endang.supriadi@walisongo.ac.id ${ }^{2}$, ririh.megah.safitri@walisongo.ac.id ${ }^{3}$, \\ muhammad.nuqlir@walisongo.ac.id ${ }^{4}$,nafisah@walisongo.ac.id $\left.{ }^{5}\right\}$
}

Universitas Islam Negeri Walisongo

\begin{abstract}
The phenomenon of radicalism and religious terrorism is still evident even in pandemic situations. The digital footprint related to radicalism and terrorism from 2020 to May 2021 is significant. At least 288 suspected terrorists have been secured by Densus 88 . During the pandemic, calls for amaliyah were massively increase carried out by radical groups. They took a chance when the government's attention focused on efforts to address Covid-19. This research related to deradicalization in Central Java was conducted using descriptive qualitative research method by placing BNPT administrators, religious organization administrators, and ulama/kiyai/Ustaz as key informants. There are two focuses in this study: (1) Optimization of deradicalization programs through the structural realm; (2) Optimization of deradicalization programs through the non-structural realm focuses on the contribution of religious organizations, nongovernmental organizations, and scholars/kyai/ustadz also grounded religious moderation's spirit to minimize radical actions.
\end{abstract}

Keywords: Radicalism; Terrorism; Deradicalization; Covid-19 Pandemic

\section{Introduction}

The diversity of the Indonesian nation is seen from the dynamics of life that people usually do. This is seen from religious life in the community. There is a wave of dynamics that continues to move. Religiousness in a moderate and radical patterned society is illustrated by the attitudes and behaviors of the community. Today, violent events in the name of religion are part of an interesting phenomenon to observe and a serious concern. In terms of understanding, movement, and action, seeing radicalism can affect the dynamics of life in society. The influence on life in the community is considerable, can be a threat to the country's economic stability, politics, and even damage the social order of society, and have an impact on people's attitudes and behavior.

Religious radicalism in society has two patterns, namely discourse, and behavior (Qodir, 2018). As a discourse, radicalism is a radical attitude implemented into the thoughts, teachings, and ideologies that are believed. This is evident from the militancy shown in propagating the teachings of Islam and how to reach them regularly continuously and indoctrinate intensely. Implemented also from his attitude that tends to be the truest of his education, others who do not adhere to his sharia are considered sinful. 
While behavioral radicalism is seen and manifested by acts of terror, this pattern is undoubtedly made not only as a matter of propagating teachings, but carrying out radical anarchist movements while committing acts of terror that damage and harm many people, not only Muslims everyone experiencing the impact of these actions. Usually, this pattern justifies all means to satisfy the desire of his passions that do not understand the actual teachings of Islam. Those who belong to the group of radicalism are usually embedded in his mind, and if others disagree with the group, then it is considered not strong faith. And even more extreme different religions are considered infidels as well as enemies of religion.

The phenomenon of religious radicalism movements that lead to terrorism becomes interesting to discuss, and even post-reform in Indonesia becomes very popular. Because religion as an identity can create the sentiments of individuals and even communities so that society in any way defends faith, seeing this, it can be said that the issue of religious ideology is often used as a starting point for violence in various problems of life in the community (Sefriyono \& Mukhibat, 2017).

The presence of radical groups that lead to acts of terror has long nested in the Indonesian community. The phenomenon of radicalism and religious-based terrorism movements postreform becomes severe and exciting to discuss. In this era of openness, all elements of society are free to act and act (Supriadi, 2018). On the other hand, his presence triggers leeway with unrestricted freedom to not rule out the possibility of nests that were once drowned reappearing in the reform era crowd (Supriadi, Ajib, \& Sugiarso, 2020). The phenomenon of religious radicalism movement boils down not only in the global context but also in Indonesia as a soft nest for radical groups.

In 2020 from June to August, the Indonesian National Police has arrested at least 72 suspected terrorists in 13 Indonesian territories. The 13 areas are among them; West Sumatra, Bali, Central Sulawesi, East Java, Central Java, West Java, Riau, Jakarta, South Kalimantan, West Nusa Tenggara, West Kalimantan, Maluku, and Gorontalo (Tim Liputan Beritasatu.com, 2020). And in 2021, the 2nd year after the Covid-19 pandemic, the security apparatus (Densus 88 ) has at least prevented terrorist groups in various regions ahead of the independence day of the Republic of Indonesia with a considerable number of 53 suspected terrorists (Detikcom, 2021). Pandemic times are a challenge for governments that are conducting deradicalization programs. Digital traces of radicalism and terrorism data, the cycle of massive radical movements are carried out in Ramadan, the celebration of the big day, and most recently ahead of the independence day of the Republic of Indonesia. There needs to be cooperation between institutions and community elements for the optimization of deradicalization programs.

Researchers, scholars, and academics have widely conducted studies on deradicalization. The library that pays attention to this theme is quite massively done as Zuly Qodir explained that stemming terrorism must start from the first door of the family because it was later known that terrorist activity and religious radicalization moved in the realm of education, whether education with a religious background or not (Qodir, 1970).

The response to the grounded discourse of moderate Islam in counteracting radicalism written by Shahram Akbarzadeh (2013) explains that the Australian government has tried to counter the threat of Islamic extremism with a "moderate Islam" narrative. This approach aimed to present counter-ideology to Islamism and proved successful. The Australian government's efforts to counter radicalization are hindered by several political, cultural, and socio-economic factors and analyze those factors considering historical, ethnic, cultural, and social conditions relevant to the Muslim community in Australia (Akbarzadeh, 2013). 
Both literature studies led that this study found its urgency. The focus of the study in this article is the first optimization of deradicalization programs through the structural realm, which refers to the performance of BNPT / FKPT. Second, the optimization of deradicalization programs through the non-structural domain focuses on the role of religious organizations such as NU and Muhammadiyah, Non-Governmental Organizations (NGOs), as well as scholars / kyai / ustadz who together ground the spirit of religious moderation to counteract radical ideas that lead to acts of terrorism in Central Java. Both foci of the study will be responded to using descriptive qualitative research methods by placing BNPT / FKPT administrators, religious organizations, and scholars / kyai / ustadz in Central Java as key informants.

\section{Results and Discussion}

\subsection{Deradicalization in Indonesia}

The series of acts of terror that continue to be carried out by radicalism and religious terrorism in Indonesia and fertile plants, dead one grows alternately. The understanding of religion that should serve as a vehicle for peaceful, friendly, and tolerant living is undermined by a misguided and petty experience in implementing it. The author understands the phenomenon of violence shrouded in religion is none other than the factors of interpretation and understanding of religion that are not appropriate to trigger the emergence of fundamentalist Muslim personalism that leads to extreme behavior towards others who do not fit the group. Different religions are considered enemies. Even one religion is not as understanding as it is also considered not following sharia. This radical understanding is what leads to acts of terror. Terror events that religious radicalism groups often carry out are religious holidays, ahead of the holy month of Ramadan and the independence day of the Republic of Indonesia. This act of terror inspired the Indonesian government to understand radicals, namely by deradicalization.

Deradicalization is one way to overcome radical understanding that leads to acts of terror. Deradicalization is part of a counter-narrative strategy related to radical understanding. According to John Horgan, deradicalization is part of changing radical understanding, but the opposite is triggering radicalism itself. Here, what is needed is not to change radical thinking, but an independent life such as economic access facilitated and avoiding violence (Horgan, 2009). The phenomenon of radicalism and religious terrorism continues to repeat itself in Indonesia, at least starting from after reformation era until 2020. The authors tried to display data on terror incidents ranging from 2000 to 2019 reported from various sources.

\begin{tabular}{|c|c|c|c|c|}
\hline Date & Event & Location & Victim & Source \\
\hline 1 August 2000 & Suicide bombing & Philippine Embassy & $\begin{array}{l}\text { Two people died and } 21 \\
\text { were injured. }\end{array}$ & (Hikam, 2016) \\
\hline September 132000 & Acts of terror & $\begin{array}{l}\text { Jakarta Stock } \\
\text { Exchange }\end{array}$ & $\begin{array}{l}15 \text { people died and } 20 \\
\text { were wounded. }\end{array}$ & \\
\hline December 242000 & Acts of terror & $\begin{array}{l}38 \text { Churches in } \\
\text { Indonesia }\end{array}$ & $\begin{array}{l}19 \text { people died, and } 112 \\
\text { were injured. }\end{array}$ & \\
\hline July 222001 & Suicide bombing & $\begin{array}{l}\text { Santa Anna Church } \\
\text { and HKBP East } \\
\text { Jakarta }\end{array}$ & 5 people died & \\
\hline September 232001 & Suicide bombing & Plaza Atrium & 6 people died. & \\
\hline October 122001 & Bomb blast & $\begin{array}{l}\text { KFC Restaurants, } \\
\text { Makassar }\end{array}$ & There are no victims & \\
\hline
\end{tabular}




\begin{tabular}{|c|c|c|c|c|}
\hline Date & Event & Location & Victim & Source \\
\hline November 62001 & Bomb blast & $\begin{array}{l}\text { Australian Schools } \\
\text { in Jakarta }\end{array}$ & There are no victims & \\
\hline October 122002 & $\begin{array}{l}\text { Suicide bombing } \\
\text { (Bali bombing } \\
\text { 1) }\end{array}$ & Bali & $\begin{array}{l}202 \text { people died and } 240 \\
\text { were injured. }\end{array}$ & \\
\hline October 252002 & Suicide bombing & $\begin{array}{l}\text { McDonald's } \\
\text { Restaurant, } \\
\text { Makasar }\end{array}$ & $\begin{array}{l}\text { Three people died and } \\
11 \text { were injured. }\end{array}$ & \\
\hline August 52003 & Suicide bombing & $\begin{array}{l}\text { JW Marriot Hotel } \\
\text { Jakarta }\end{array}$ & $\begin{array}{l}12 \text { people died and } 150 \\
\text { were injured. }\end{array}$ & \\
\hline September 92004 & Acts of terror & Australian Embassy & $\begin{array}{l}\text { Eight people died and } \\
115 \text { were injured. }\end{array}$ & \\
\hline October 12005 & $\begin{array}{l}\text { Suicide bombing } \\
\text { (Bali bombing } \\
\text { 2) }\end{array}$ & Bali & $\begin{array}{l}26 \text { people died and } 110 \\
\text { were injured. }\end{array}$ & \\
\hline July 172009 & Bomb blast & $\begin{array}{l}\text { JW Marriot Hotel } \\
\text { and Ritz-Carlton } \\
\text { Jakarta }\end{array}$ & $\begin{array}{l}\text { Dozens of people were } \\
\text { injured. }\end{array}$ & $\begin{array}{l}\text { (Kompas.com, } \\
\text { n.d.) }\end{array}$ \\
\hline September 2010 & $\begin{array}{l}\text { There was a } \\
\text { shooting at the } \\
\text { civil society. }\end{array}$ & $\begin{array}{l}\text { Robbery at BANK } \\
\text { CIMB Niaga, Aceh }\end{array}$ & 1 person injured & \\
\hline 15-17 March 2011 & Book bomb & Jakarta & There are no victims & (Okezone.com, \\
\hline April 152011 & Suicide bombing & $\begin{array}{l}\text { Mapolresta Cirebon } \\
\text { Mosque }\end{array}$ & 25 people were injured. & 2016) \\
\hline September 252011 & Suicide bombing & Solo & $\begin{array}{l}\text { One person died and } 28 \\
\text { were injured. }\end{array}$ & \\
\hline 19 August 2012 & Bomb blast & $\begin{array}{l}\text { Pospam Gladak, } \\
\text { Solo }\end{array}$ & $\begin{array}{l}\text { Dozens of people were } \\
\text { injured. }\end{array}$ & $\begin{array}{l}\text { (BBC Indonesia, } \\
\text { n.d.) }\end{array}$ \\
\hline June 32013 & Suicide bombing & $\begin{array}{lr}\text { Mapolres } & \text { Poso } \\
\text { Mosque, } & \text { Central } \\
\text { Sulawesi } & \end{array}$ & One person died. & \\
\hline January 142016 & $\begin{array}{l}\text { Suicide } \\
\text { bombings and } \\
\text { shootouts }\end{array}$ & $\begin{array}{l}\text { Plaza Sarinah, Jl. } \\
\text { MH. Thamrin } \\
\text { Central Jakarta }\end{array}$ & One person died. & $\begin{array}{l}\text { (Tribun Pontianak } \\
\text { Online, 2016) }\end{array}$ \\
\hline July 52016 & Suicide bombing & $\begin{array}{l}\text { Surakarta City } \\
\text { Resort Police } \\
\text { Headquarters }\end{array}$ & $\begin{array}{l}1 \text { person died (police } \\
\text { officer) }\end{array}$ & \\
\hline 28 August 2016 & Suicide bombing & $\begin{array}{l}\text { St. Joseph's Stasi } \\
\text { Catholic Church, } \\
\text { Medan City }\end{array}$ & Injured & \\
\hline November 132016 & Bomb blast & $\begin{array}{l}\text { Front of Oikumene } \\
\text { Church of } \\
\text { Samarinda } \\
\text { Kaltim }\end{array}$ & $\begin{array}{l}1 \text { person died and } 4 \\
\text { children were lightly } \\
\text { injured. }\end{array}$ & \\
\hline 14 November 2016 & Bomb blast & $\begin{array}{l}\text { Budi Dharma } \\
\text { Monastery } \\
\text { Singkawang City, } \\
\text { Kalbar }\end{array}$ & 3 people injured & \\
\hline October 202016 & $\begin{array}{l}\text { Acts of assault } \\
\text { on } \\
\text { officers }\end{array}$ & Cikokol & There are no victims & $\begin{array}{l}\text { (Tim Liputan } \\
\text { CNN, 2019) }\end{array}$ \\
\hline 27 February 2017 & $\begin{array}{l}\text { Bom panci } \\
\text { meledak }\end{array}$ & $\begin{array}{l}\text { Pandawa Cicendo } \\
\text { Park, Bandung }\end{array}$ & There are no victims & $\begin{array}{l}\text { (Tribunnews.com, } \\
\text { 2017) }\end{array}$ \\
\hline 24 May 2017 & $\begin{array}{l}\text { Bom panci } \\
\text { meledak }\end{array}$ & $\begin{array}{l}\text { Kampung Melayu, } \\
\text { East Jakarta }\end{array}$ & $\begin{array}{l}\text { Three police officers and } \\
\text { two suspects died, and } \\
14 \text { were lightly injured. }\end{array}$ & \\
\hline April 112017 & $\begin{array}{l}\text { Attack on police } \\
\text { station }\end{array}$ & $\begin{array}{l}\text { Mapolres } \\
\text { Banyumas }\end{array}$ & $\begin{array}{l}1 \text { person was slightly } \\
\text { injured }\end{array}$ & $\begin{array}{l}\text { (Tim Liputan } \\
\text { CNN, 2019) }\end{array}$ \\
\hline June 302017 & Stabbing & Falatehan Mosque & 1 person was slightly & \\
\hline
\end{tabular}




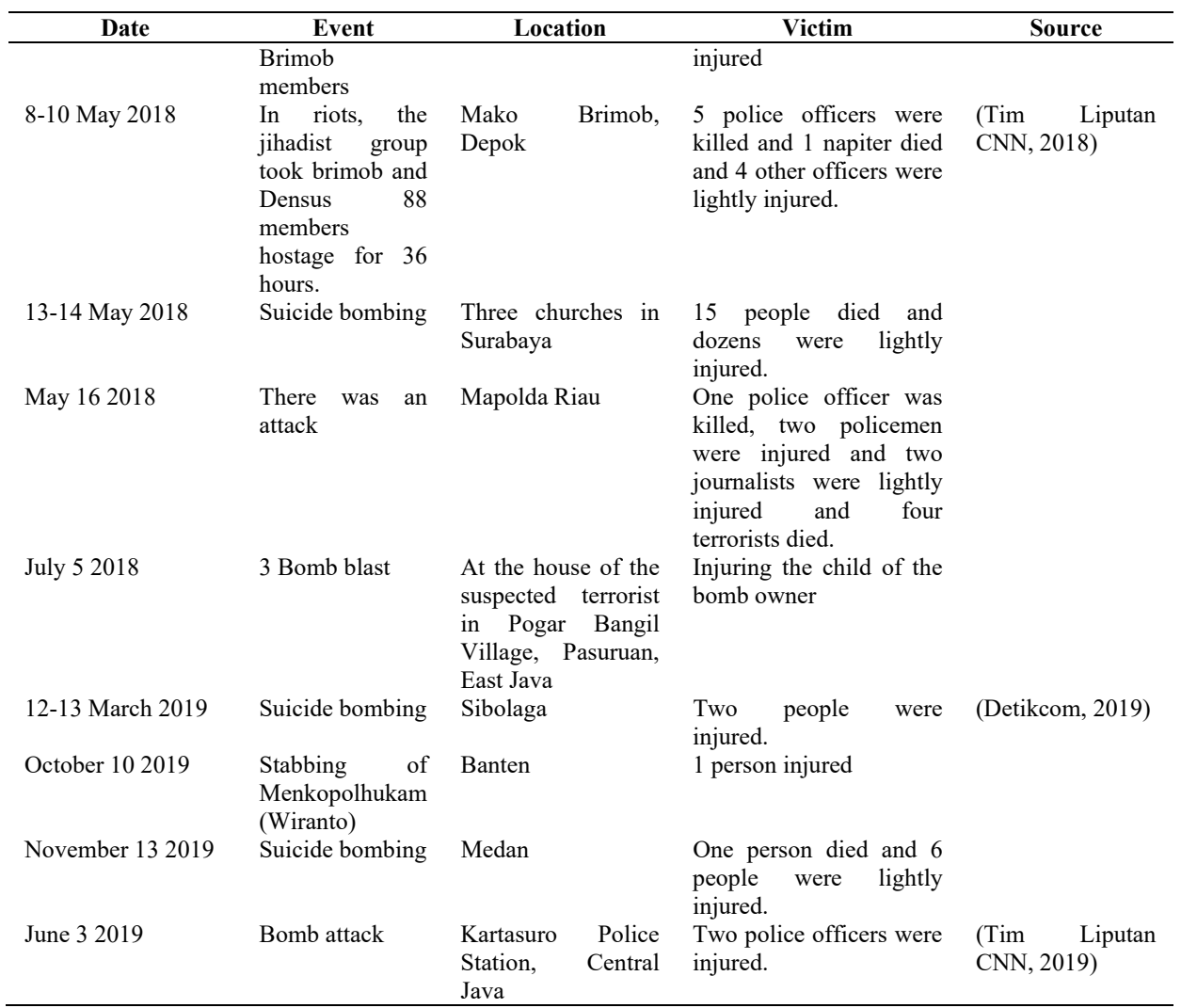

The series of acts of terror that occur simultaneously, as described above, gives a signal to the Indonesian government, and this incident is not a joke because it has killed more than hundreds of innocent human souls. There need to be preventive measures to tackle radicalism and terrorism.

The government has taken many approaches to prevent radical understanding, ranging from hard and soft power approaches. Both methods seem unable to break radicalism. So there needs to be another approach that can reduce the radical understanding of religion that leads to acts of terror in the community. And there must be the involvement of all elements of civil society to prevent and counter the radicalism and religious terrorism that continue to grow simultaneously in society. Prevention efforts carried out by BNPT to overcome radicalism, and religious terrorism led to the same incident. The Covid-19 pandemic should be a serious concern by the government. In this case, BNPT massively prevents radical understanding. Because the phenomenon of Covid-19 can be used as a land to recruit members or influence community thinking. Amaliyah's invitation during the Covid-19 pandemic can endanger national stability. BNPT, with its deradicalization program, needs to be active and passively monitor and prevent radical understanding. 


\subsection{The development of deradicalization in Central Java}

\subsubsection{Involvement of Central Java FKPT in Stemming Radical Understanding}

The Central Java Coordinating Forum for prevention of terrorism (FKPT) began with the phenomenon of intolerance, radicalism, which led to acts of terror that have become a national problem in Indonesia. Various acts of terror bombings that initially attacked places of worship and tourism locations visited by many foreign nationals, as has happened on the island of Bali. Acts of terror are now developing and spreading to wider targets to public facilities, such as offices, attacking security forces, and self-harm, such as suicide bombings.

Events that the above terrorism groups often show have formed trauma among Indonesian people in particular. In addition to killing lives, acts of terrorism also impact society, namely the suspicion of socio-religious conflict in the community. In addition, acts of terrorism also threaten the existence of the unity of the Republic of Indonesia. Acts of terrorism like this should be understood as a movement different from other radical movements, such as radical ideas, radical militias, non-terrorist radicals, and separatist radicals. The difference between a revolutionary terrorist movement and other radical movements in society does not lie solely in the target shot. However, the difference that exists is the difference in the process of phasing out radicalization in it.

The author looks at the various acts of terrorism in Indonesia not caused by a single factor but the accumulation of causes that include social, political, economic, religious, and cultural interpretation problems. And what the government is doing against terrorist perpetrators is a hard approach, which puts law enforcement as the only way out. As is the case in health science theory, the core factor is that the virus must be quarantined to avoid spreading infectious diseases. Thus the challenging approach in the handling terrorism should be seen as an attempt to quarantine the terrorist virus so as not to spread widely and its terror cells are cut off. In addition to using the above challenging approach, the prevention of terror acts must be carried out immediately by all elements of society. These efforts must be carried out in a holistic manner that is well-coordinated and integrated between elements of society. Likewise, rehabilitation efforts against the perpetrators of acts of terror and the family must also be made together massively and sustainably. This is called a soft approach.

The government has responded to the events of terrorism in Indonesia with the establishment of the National Agency for Counter-Terrorism (BNPT), including the establishment of FKPT. However, this formation is felt less because it needs to contribute from all elements of society. Knowing this, FKPT Central Java cooperates with all elements of society to prevent terrorism. According to the chairman of FKPT Central Java, Syamsul Ma'arif said that those involved in preventing terrorism are students and journalists (interview on August 20, 2021). The involvement of students in the prevention of terrorism is prevention by using soft methods by providing an early understanding to the public about the dangers of radicalism and terrorism. Another effort made by FKPT Central Java is to synergize, educate and inject ideology through institutions with young millennials by upgrading a joint strategy against terrorism.

\subsubsection{The Role of Religious Organizations in Understanding Radicals}

Various strategies in counteracting radical understanding have been widely carried out by the government, ranging from building dialogue, cooperation, peace forums to deterrence by means of hard power. The involvement of community organizations is considered so 
important based on the idea that the government has limitations, such as funding resources, human resources, and technology; the participation of the community, ulama / kyai / ustadz is very important to stem radicalism.

Radicalism is the root of acts of terrorism that have a complex network that can be approached with a law enforcement approach and the need for community involvement, especially religious leaders or scholars. In stemming radicalism in Central Java, NU and Muhammadiyah scholars or other religious organizations have strategic measures. The steps in the prevention of radicalism certainly offset the phenomenon that occurs in some regions. In this case, scholars have a role in providing an understanding of the correct creed by not ruling out the values of diversity and nationality as provisions to prevent friction between Muslims and religious people and avoid radical teachings to prevent acts of violence in the name of religion.

NU and Muhammadiyah scholars carried out the strategy in blocking radicalism by using counter-radicalization and deradicalization strategies through structural and cultural approaches. Efforts that have been made by NU and Muhammadiyah scholars such as da'wah in various media, asset control as an effort to reduce the spread of radical understanding in institutions, especially NU and Muhammadiyah institutions, and strengthening nu and Muhammadiyah citizens. These two religious organizations become pillars in efforts to prevent radicalism from answering the challenges of radical group movements and further building internal synergy with managers both in NU and Muhammadiyah both at the regional level, branches, branch representatives to branches and build synergy with the government apparatus to be more swift in dealing with the movement of radical groups.

\section{Conclusion}

Portraits of the journey of radical groups in their acts of terror look massive before and after the BNPT. The series of terror acts by radicalism and religious terrorism from 2000 to 2021 proves that Indonesia's deradicalization program has not found the right formula to prevent radicalism. In order to stem and reduce the influence of radicalism and religious terrorism, hard power, and softer approaches have not been effective. Coupled with the presence of the Covid-19 pandemic in Indonesia becomes its work to ward off radicalism and religious terrorism.

The Covid-19 pandemic is an extraordinary phenomenon, as well as deradicalization. The government's attention must comprehensively look at all the nation's problems. One side is facing the problem of Covid-19; the other side of radicalism and religious terrorism can take advantage of this moment for their amaliyah actions. Digital footprint during the Covid-19 pandemic police officers (Densus 88) has secured approximately 125 suspected terrorists spread across several regions in Indonesia. NU and Muhammadiyah scholars play a role in exploring radicalism in Central Java. The strategy carried out by NU and Muhammadiyah is to use counter-radical strategies and deradicalization through structural and cultural approaches. The involvement of religious organizations, scholars, and NGOs in deradicalization programs is needed to ground the spirit of religious moderation amid the currents of radicalism. The contribution of every element of society can at least break the chain of radicalism and religious terrorism in Central Java. 


\section{References}

[1] Akbarzadeh, S. (2013). Investing in Mentoring and Educational Initiatives:The Limits of De-Radicalisation Programmes in Australia. Journal of Muslim Minority Affairs. https://doi.org/10.1080/13602004.2013.866347

[2] BBC Indonesia. (n.d.). Bom Bunuh Diri Mapolres Poso.

[3] Detikcom, T. (2019). "Kronologi Penusukan Wiranto di Pandeglang." Detiknews.

[4] Detikcom, T. (2021). 53 Terduga Teroris yang ditangkap Jelang Hari Kemerdekaan Incar Pemerintah. Detiknews. Retrieved from https://news.detik.com/berita/d5690066/53-terduga-teroris-yang-ditangkap-jelang-hari-kemerdekaan-incarpemerintah?_ga=2.147918391.1801190542.1630109558-480594994.1540795212

[5] Hikam, M. A. (2016). Peran Masyarakat Sipil Indonesia Membendung Radikalisme Deradikalisasi. Kompas.

[6] Horgan, J. (2009). Walking away from terrorism: Accounts of disengagement from radical and extremist movements. In Walking Away from Terrorism: Accounts of Disengagement from Radical and Extremist Movements. https://doi.org/10.4324/9780203874738

[7] Kompas.com. (n.d.). Ledakan di JW Marriot dan Ritz, 8 Warga Asing Terkapar.

[8] Okezone.com. (2016). Bom Bunuh Diri terjadi di Sebuah Gereja di Meda.

[9] Qodir, Z. (1970). Deradikalisasi Islam dalam perspektif pendidikan agama. Jurnal Pendidikan Islam. https://doi.org/10.14421/jpi.2013.21.85-107

[10] Qodir, Z. (2018). Kaum Muda, Intoleransi, dan Radikalisme Agama. Jurnal Studi Pemuda. https://doi.org/10.22146/studipemudaugm.37127

[11] Sefriyono, S., \& Mukhibat, M. (2017). Radikalisme Islam: Pergulatan Ideologi ke Aksi. Al-Tahrir: Jurnal Pemikiran Islam. https://doi.org/10.21154/altahrir.v17i1.815

[12] Supriadi, E. (2018). Measuring the Importance of Stemming Radicalism In the Decentralization Era of Democracy. MIMBAR: Jurnal Sosial Dan Pembangunan. https://doi.org/10.29313/mimbar.v34i2.3451

[13] Supriadi, E., Ajib, G., \& Sugiarso, S. (2020). Intoleransi dan Radikalisme Agama: Konstruk LSM tentang Program Deradikalisasi. JSW (Jurnal Sosiologi Walisongo), 4(1), 53-72. https://doi.org/10.21580/jsw.2020.4.1.4544

[14] Tim Liputan Beritasatu.com. (2020, August 18). 72 Terduga Teroris Diciduk, Polisi Bongkar Rencana Aksi Teror. Beritassatu.Com.

[15] Tim Liputan CNN. (2018, November 9). "Kronologi Tiga Kali Ledakan Diduga Bom di Bangil Pasuruan." CNN Indonesia.

[16] Tim Liputan CNN. (2019). Rentetan Bom dan Aksi Terorisme Selama Ramadhan di Indonesia.

[17] Tribun Pontianak Online. (2016, November 14). "Breaking News: Vihara Budi Dharma Singkawang Dilempari Bom Molotov." Newspaper.

[18] Tribunnews.com. (2017). "Pelaku Bom Panci Cicendo Anggota Kelompok JAD Bandung." Tribunnews.Com. 